66 Beeston is one of six men at the Red Bull named in an order for repair of the highways by the theatre, dated 3 October 1622; see Bentley, The Jacobean and Caroline Stage, 1.169 n.2. As he had managed Queen Anne's Men there, and returned there with them after the 1617 riot, it appears that he owned, and continued to own, the theatre.

67 For 'bifold appeal' see discussion in Rutter, Work and Play, 110.

68 Exceptions include the Red Bull Revels' Two Merry Milkmaids, at court in 1619/20, and Gramercy Wit in 1621; see Bentley, The Jacobean and Caroline Stage, 1.173.

\title{
Romeo at the Rose in 1598
}

In two plays of the Lord Admiral's Men - Englishmen for My Money and The Two Angry Women of Abingdon - echoes of Romeo and Juliet appear. ${ }^{1}$ The first performances of Englishmen took place at the Rose in 1598. Two Angry Women is likely to have played at the same venue in the same year. What may these echoes tell us about the ethos and practices of the Lord Admiral's Men, about the dramatists who wrote for them, and about the company's place in the literary and dramatic milieu of the time?

I want to argue that the presence of these echoes reveals a degree of integration into urban literary fashion. And I will also suggest that some of the company's playwrights exhibit the kind of knowing playfulness that was soon to characterize the repertory of the children's companies and which was already shaping the satires and epigrams to reach print publication at this time. In other words, I suggest that those who wrote for the Admiral's company may have had more in common with the young and iconoclastic writers of verse satire and of experimental drama for the indoor companies than commentators have often thought.

The Admiral's Men, theatre historians frequently assume, had a repertory aimed at non-elite audiences. One line of thought, which Roslyn Lander Knutson vividly and critically summarizes in The Repertory of Shakespeare's Company 1594-1613, contrasts the Admiral's repertory with that of the Lord Chamberlain's Men. A heightened regard for Shakespeare's company colours this distinction, with the purveyor of formulaic plays set against the sponsor of sublime drama, while our access to Henslowe's papers, with their starkly commercial concerns, underpins the contrast. ${ }^{2}$ The binary is still in evidence in the work of Andrew Gurr, who in Playgoing in Shakespeare's London takes 
'Juliet's rebellion' as a kind of touchstone by which to evaluate the Admiral's repertory. From around 1600, Gurr argues, the Admiral's Men espoused 'citizen views about marriage' that contrasted with a value upon 'the power of love over parental authority' as held by the Lord Chamberlain's Men. ${ }^{3}$

If scholarship has at times placed the Admiral's company on one side of the Lord Chamberlain's Men, on the other side appears the fashionable world of the children's companies: companies that served a coterie audience, partly comprising London's law students. A feature of these companies was a readiness to commandeer a shared awareness of dramatic catchwords and theatrical allusion. In this regard, these companies perhaps formed a kind of avant-garde. ${ }^{4}$

The Admiral's Men are not generally thought to have participated in this culture. And yet, I shall argue, we can glimpse signs of a writerly self-consciousness within the Admiral's repertory just as we can in the repertories of Paul's or the Children of the Chapel. By attending to plays as the products of writers and of companies alike, I suggest, we help ourselves to understand the context both of individual playwriting endeavour and of corporate company behaviour.

We know from Henslowe's records that William Haughton wrote $A$ Woman Will Have Her Will in early 1598. ${ }^{5}$ It reached print publication in 1616 as Englishmen for My Money; or, A Woman Will Have Her Will. The text of 1616 presumably represents something very close to the words that spectators at the Rose would have heard at some point during the year of its composition. The relationship between text, composition, and performance is less straightforward for The Two Angry Women of Abingdon, even though the play twice appeared in quarto form in 1599, declaring its company provenance upon the title-pages. The problem is that Henslowe does not mention the first part of any play of that name, although records from late 1598 and early 1599 mention a sequel. ${ }^{6}$ Scholars used to consider that the original Two Angry Women must have been composed in the 1580s, based on an apparent allusion to the play in $1590 .^{7}$ But this hypothesis is far too dependent upon a correspondence for which other explanations are available. ${ }^{8}$ More telling is the clear tendency in Henslowe's papers for sequels to follow closely the early performances of the 'first part'. These papers are partial and inexact records, not comprehensive ones. ${ }^{\text {T }}$ They may have omitted any mention of the work that led to the published Two Angry Women or this work may appear under another name. Two Angry Women was probably composed and first performed in 1598 and almost certainly enjoyed a showing at the same time as the sequel. 
'How smug this gray-eyed Morning seems to bee: / A pleasant sight' (Englishmen 1.1.1), says Pisaro as he opens Haughton's play. Friar Laurence had begun his own solitary aubade on his first appearance in Romeo and Juliet: 'The greyeyed morn smiles on the frowning night' (2.2.1). ${ }^{10}$ Although in calculating his mercantile profit Pisaro shows himself to be more like Barabas than any character from Romeo, he does refer to 'this airy region' (Englishmen 1.1.7), matching Shakespeare's 'through the airy region stream so bright' (Romeo 2.1.63). Pisaro's three daughters love three Englishmen but Pisaro intends to match them with foreign suitors. Of course, the daughters gain their chosen husbands and humiliate Pisaro's candidates. The unauthorized courtship largely takes place at night, during scenes in which the daughters appear on the upper level and speak to the men below. The Dutchman, Vandalle, impersonating one of the Englishmen, is invited to ascend in a washing basket and left to dangle halfway. The play presents a conflict between parents and children, and also between rival suitors, and it presents nocturnal balcony love scenes.

How far may we fairly assume a verbal indebtedness to Shakespeare? Other examples of 'grey-eyed' mornings exist, though these seem to occur after the time of Romeo and Juliet, and Marlowe, as well as Shakespeare, wrote of an 'airy region' (4.1.119). ${ }^{11}$ The common structural features of the two plays certainly invite us to see a connection, though they do not compel us to do so. The expression that does do this, I would argue, is Pisaro's 'Night's candles burn obscure' (Englishmen 2.3.345). This recalls 'Night's candles are burnt out' (Romeo 3.5.9), and here the verbal overlap is sufficiently precise to allow us to presume a dependency. ${ }^{12}$ This overlap suggests that the other likenesses were also borrowings and even that the English suitor's question to Pisaro, 'What, would you wed your daughter to a grave?' (Englishmen 5.1.125), looks back to Capulet's 'I would the fool were married to her grave' (Romeo 3.5.140). These similarities suggest conscious recollection rather than unwitting echo. Pisaro's close involvement points to his place as a father determined to select husbands for his daughters. In this aim, of course, he resembles old Capulet. That three of the echoes involve the attempt to indicate the setting of the scene and to evoke a certain atmosphere may also be significant. We may remember that Romeo, like Englishmen, was a nocturnal: a play with significant scenes set at night.

The same overlap is true of The Two Angry Women of Abingdon. The correspondences between Romeo and Juliet and Porter's comedy are stronger than those between Romeo and Englishmen. Porter's play presents two families with a background of friendly relations rather than enmity, but between 
whose mistresses a sudden quarrel breaks out. The ineffectual husbands are unable to persuade their wives to make up. Instead, they promote a match between their children. The couple — Frank and Mall — meet at night after Mall's brother Philip brings Frank to stand below her window. The lovers come to an agreement, though they subsequently face opposition from their mothers. As in Englishmen, comedy takes over and a nocturnal farce ends with marriage and reconciliation.

The lovers' encounter, then, takes place against parental opposition. It also features lovers whose parents are at loggerheads, and so its context resembles Romeo in a way that Haughton's casement episode does not. Porter also follows Shakespeare in the local management of his stage assignation. The play directs attention toward a single couple, although Philip's role, both as facilitator and commentator, is substantial. An interruption from offstage punctuates the conference. And yet, for all this similarity, the scene's mood does not resemble that of Shakespeare's play. Until they reach an abrupt accord, Mall and Frank engage each other in a battle of wits. Mall is decidedly the sharper of the two, and we do not get the sense that she is showing a brittle front behind which she marshals feelings too powerful for expression. Philip has indeed advertised her as likely to test Frank by her combativeness. Philip's own participation in the scene accentuates the bawdy at the expense of what is moving.

Verbal echoes of Romeo appear at this point in Porter's play. Mall says to Frank, 'methinks you speak without the book', reminding Marianne Brish Evett of Juliet's 'you kiss by th' book'. ${ }^{13}$ Mall's mother objects to the match: 'I'll rather have her married to her grave' (Two Angry Women 8.175) — which looks back to the line recalled in Haughton's play. When Frank calls for Mall to descend from the upper level by saying, 'Bid her come seal the bargain with a kiss' (Two Angry Women 8.130), he echoes Romeo, who, about to down his poison, says that he will 'seal with a righteous kiss / A dateless bargain to engrossing death' (Romeo 5.3.114-5). ${ }^{14}$ Given that the play's male lover speaks each line, a minimal parallelism exists beyond the similarity of the language.

Although the lovers contribute to the insistent bawdy of this assignation scene, Philip dominates the conversation, repeatedly interjecting his own cynical opinions. No such figure appears onstage during Shakespeare's balcony encounter, but an origin may lie in Mercutio, who immediately before the lovers' interview in Romeo offers an earthy and anti-romantic tirade. Shakespeare's lovers, of course, effectively deflate their critic as the passionate 
intensity of their own meeting outstrips its denigration. Porter, however, seeks no such deflation: the lovers themselves engage in bawdy play and verbal sparring, and Philip's jaundiced attitude has nothing substantial against which to work.

The character who does speak an approximation to the lovers' language of Romeo and Juliet is Philip himself when - two scenes later and alone on stage — he says:

How like a beauteous lady masked in black

Looks that same large circumference of heaven.

The sky that was so fair three hours ago

Is in three hours become an Ethiope,

And being angry at her beauteous change,

She will not have one of those pearlèd stars

To blab her sable metamorphesy. (Two Angry Women 10.1-7)

Evett considers that the 'closest analogue' to this passage is:

It seems she hangs upon the cheek of night

As a rich jewel in an Ethiope's ear. ${ }^{15}$

We could add that Porter's passage conflates this simile with Romeo's hyperbole on the subject of 'the envious moon' (Romeo 2.1.46ff.), and that the 'metamorphecy' blabbed by 'those pearled stars' may reflect the extended conceit of the eyes/stars exchange later in Romeo's speech (Romeo 2.1.57ff.). The figurative language of Shakespeare's play suffuses Philip's lines and provides at once the strongest evidence for the fact of the connection and the most valuable site for exploring the possible purposes at play.

To what end, if any, did Porter fill the speech with borrowings? In particular, why should Philip, the cynic of the earlier scene, speak the verse? Michael Jardine and John Simons think that the fact that he is not the play's lover itself points toward parody. ${ }^{16}$ The play's tendency, which is here dropped, to place allusions in the mouths of broadly corresponding characters argues an attempt to evoke Romeo and Juliet, but the willingness to abandon this practice, and the lack of obvious satiric purpose to each local echo, strongly suggest the limits to any systematic strategy in Porter's use of the tragedy. The undirected manner of Porter's playful allusiveness is what makes it difficult to assess the nature of his borrowing from Romeo and Juliet. Evett, for 
instance, searches for a motive behind the presence of the echoes: 'These parallels may suggest Porter's gentle but conscious burlesque of Romeo and Juliet, or, indeed, it may be that Porter was incapable of writing about crossed lovers and arguing families without thinking of Shakespeare's very different but very powerful play'. ${ }^{17}$ Evett is right to be undogmatic about Porter's possible purposes, for writerly intentions in this regard are not easy to determine and the intermittent verbal borrowings do not really furnish enough evidence to support an assured theory about these purposes.

What may we fairly say about the recourse to Romeo and Juliet in Englishmen and Two Angry Women? First, of course, it suggests the impact of the tragedy, but that is not the point at issue here. Second, it enhances, rather than depresses, a sense that the repertory of the Admiral's Men was outward-looking and that it developed in some kind of tension with the offerings of its principal competitor. Third, it suggests a kind of playfulness to the composing habits of at least two of the company's playwrights. And lastly, and perhaps most significantly given the shared night-time setting of crucial scenes from the two comedies, the borrowings from Romeo may have supported the nocturnal genre of the two debtor plays. We may reasonably suspect that by using the language of Shakespeare's romantic tragedy, the Admiral's dramatists developed the atmospheric quality of their own two dramas.

Of course, the indebtedness that this essay explores is simply one part of a limitless tendency of stage writers to appropriate the words and ideas of others. Romeo and Juliet has many analogues that precede as well as follow Shakespeare's play, and thwarted lovers, opposing households, and sardonic companions featured regularly in the drama of the 1590s and beyond. Romeo was only one such influence upon Englishmen and Two Angry Women. For plays of the Admiral's Men, furthermore, the legacy of Christopher Marlowe was constant and powerful. The presence of Alleyn in the playing company during the years after Marlowe's death and the persistence of Marlowe's drama within the Admiral's repertory ensured that the influence of the playwright remained strong. ${ }^{18}$ As I mentioned earlier, Englishmen demonstrates this influence precisely in the figure of Pisaro, whose conception clearly drew shape from The Jew of Malta's merchant Barabas. The Jew of Malta, indeed, may itself have helped to shape the language of Romeo and Juliet, as Tom Rutter mentions in introducing these essays. ${ }^{19}$

Beyond all these considerations is the wider question of what exactly we make of the practice of verbal borrowings. Just as the study of repertories 
may divert our gaze away from the activity of the writer and toward company considerations, so an attention to the appropriation of language directs us to what is common between plays rather than to what may be distinctive or even unique. In this instance, my effort is to reflect upon the way that institutional allegiance may or may not affect the manner in which individual writers reveal an engagement with Romeo and Juliet, and the focus for this effort is the year of 1598 .

1598 was the year of the anonymous appearances of Skialetheia, Pygmalion's Image, and The Scourge of Villainy. ${ }^{20}$ It was the year in which Frances Meres offered his account of active writers within Palladis Tamia, Every Man In His Humour reached the stage, and Shakespeare's name first appeared as author upon a print publication of a play. ${ }^{21}$ Chapman also first emerged in this year as a named dramatic writer. ${ }^{22} 1598$ was the last year before the burning of erotic and satiric publications under the bishops' ban. ${ }^{23}$ It was also the final year before the indoor theatre at Paul's opened and the fashionable phenomenon of the children's companies emerged. ${ }^{24}$

In presenting this historical overview, a danger emerges in drawing too strongly a narrative of literary change. Yet the arrival of new and innovative dramatic writers, the reopening of the children's companies, and the shift in title-page attributions of plays do indeed appear to be significant and distinctive changes. It is reasonable to place all these developments alongside the vogue for Juvenalian satire, a phenomenon that also flourished during the last years of the 1590s. Indeed, in 1598, readers of The Scourge of Villainy heard that the young gallant Luscus spoke 'Naught but pure Juliat and Romio'. ${ }^{25}$ In the second of the three Parnassus plays another affected young man - Gullio - appears, and he too is eager to impress with his quotations from the tragedy. 'We shall have nothinge but pure Shakespeare and shreds of poetrie that he hath gathered at the theators', Ingenioso comments wryly (11. 985-6). ${ }^{26}$ This university comedy and the verse satire furnish telling evidence. Romeo and Juliet was clearly becoming a fashionable currency and the play's over-keen admirers were the cause of amusement.

The companies at Paul's and Blackfriars quickly exploited this irreverent and allusive culture. In the first years of the second Paul's company, a series of casement episodes takes place, and each play offers an engagement with Romeo and Juliet. Antonio and Mellida speak the extravagant language of Petrarchan love. ${ }^{27}$ In Jack Drum's Entertainment Pasquill and Katherine come to a lovers' accord after she has disposed of two previous suitors. ${ }^{28}$ Blurt, Master Constable three times plays upon the lines, 'It seems she hangs upon 
the cheek of night / As a rich jewel in an Ethiope's ear', following not only Two Angry Women but also Jack Drum. ${ }^{29}$ The casement interviews between Lady Lentulus and Mendosa in The Insatiate Countess and between Maria and Gerardine in The Family of Love may have taken place at the same theatre and close to the same time. ${ }^{30}$ These plays share many interconnections. The unjust guardian motif, the prominence of warring families, the place of the rejected suitor, the presence of an entourage below the balcony, the intermingling with a second debt to another play, the involvement of a scoffing companion, a ladder of ropes together with the lover's fall to the ground: all of these characteristics recur. Most features may be traced to Romeo and Juliet itself, if only at second hand, and others take on an independent life of their own. At Blackfriars, the Julia and Ovid of Poetaster and the Freevill and Beatrice of The Dutch Courtesan continue the engagement.

Detecting allusions and evaluating the tone of their deployment are not exact sciences. Common sense, proportion, and the assessment of what is reasonable are the tools at a critic's disposal. For some readers the list of echoes suggested here may be too long and for others the proposed interconnections may be too elaborate. But we may reasonably see in the repertory of Paul's, at least, a sustained and developing engagement with Romeo and Juliet. It is also fair to see Englishmen and Two Angry Women as part of the prehistory to subsequent recreations of the staging and the speeches of Romeo and Juliet. For example, the background of disapproval from parents or guardians to feature in Antonio and Mellida, Poetaster, and The Family of Love, and which was so strong a feature of Juliet's own situation, had its first encores in the two comedies played at the Rose. And later plays repeat, in various ways, the dependency of Englishmen's opening line on Shakespeare's 'The grey-eyed morn smiles on the frowning night. ${ }^{31}$

I do not attempt here to describe in detail the place of the two Admiral's plays within a progressive account of Romeo's reception; rather, I wish to show that they did indeed hold such a position. The case that the Admiral's Men were part of this intertextual narrative - indeed, that the Admiral's Men were at its start - may influence our view of the company and of the individuals who were its writing agents. It may suggest that the writing culture of the Admiral's dramatists was less removed from that of the iconoclastic satirists and the writers for childrens' companies than commentators have sometimes suspected.

This possibility brings us to the place of the Admiral's as a home for inexperienced literary dramatists. Marston (briefly), Jonson (more frequently), 
and Chapman (intensively) were hired by the company. ${ }^{32}$ So was Drayton; so, later, would be Webster and Middleton. ${ }^{33}$ Clearly, writers that we might characterize as literary, or privileged, or innovative, or independent, or elite, were among those to whom the Admiral's Men turned. We could easily see this aspect of the Admiral's operation as atypical, or even as odd or amusing. For Cyrus Hoy, Marston was 'an exotic bird of passage in Henslowe's drab world'. ${ }^{34}$ But this presence within the affairs of the Admiral's Men is a persistent one. Is it indeed atypical?

We know very little about Haughton and Porter beyond Henslowe's notes. No early modern publication names Haughton upon its title-page. Englishmen appeared anonymously, as had Patient Grissil in 1603.35 Grim the Collier of Croydon, or The Devil and His Dame was unpublished until the Restoration, when it emerged as the work of 'I.T.. ${ }^{36}$ The Protectorate appearance of Lusts Dominion; or, The Lascivious Queen named Christopher Marlowe as the play's author. ${ }^{37}$ Without the evidence of Henslowe's papers, we would not know that a dramatist named William Haughton existed, let alone be in a position to connect him with specific plays. With the benefit of Henslowe's testimony, we are aware that Dekker, Haughton, and Chettle were paid for Patient Grissill in December 1599. ${ }^{38}$ Grim the Collier of Croydon is presumably a version of Haughton's independently written play of May 1600, The Devil and his Dam. ${ }^{39}$ Three months earlier Dekker, Day, and Haughton had collaborated upon The Spanish Moor's Tragedy, and scholars believe that this activity contributed to the text of Lust's Dominion. ${ }^{40}$ This last play features a further reprise upon Romeo and Juliet, for the 'Lascivious' Queen Mother's 'Would I were covered with the vail of night, / You might not see red shame sit on my cheek' rather improbably echoes Juliet's 'Thou knowest the mask of night is on my face, / Else would a maiden blush bepaint my cheek'. ${ }^{41}$ If these lines were indeed spoken at the Rose then both Haughton and Marston would be among the candidates for their composition. ${ }^{42}$

The testimony of Haughton's largely collaborative and problematic corpus is murky. On the evidence of Englishmen, he had the capacity of his collaborators Thomas Dekker (the author of The Whore of Babylon), John Day (The Isle of Gulls), and Henry Chettle (Hoffman) to produce a work at once distinctive and creatively dependent. Englishmen for My Money is a skilful play, though it is not easy on the modern palate; its handling of the Dutch, French, and Italian suitors promoted by Pisaro is rough, and the comedy is of particular interest to scholars keen to explore its treatment of national identity and cultural difference. ${ }^{43}$ 
Two Angry Women is Porter's only known surviving work. G.K. Hunter notes that its title-page "calls Porter "Gentleman," and for all his unreliability he appears in the record as a person of considerable presence, prized by the actors as a valuable property'. ${ }^{44}$ Henslowe may record something more than mere unreliability: as 1599 progresses Porter is the recipient of several unusually small payments, and this record also appears:

harey porter tocke \& a somsete of me Phillip henslowe the 16 of Ap ${ }^{\mathrm{r} e l l} 1599$ vpon this condion that yf I wold geue hime xij $\mathrm{d}$ at that Instante for that xij $\mathrm{d}$ he bownd hime seallfe vnto me in xli of corant Inglesh money for this cawse to paye vnto me the next daye folowinge all the money wch he oweth vnto me or els to forfette for that xij $d$ tenn powndes wch deate wase vnto me xxvs wch he hath not payd acordinge to his bond $\&$ so hath forfetted vnto me wittnes to this a somsette. 45

Some marked distress or dependency seems at play here. Porter's Two Angry Women survives as a solitary work of merit and energy, and as a comedy that its spectators clearly relished. Porter might have rivalled Marston, Jonson, and Chapman as a dramatist had he lived and thrived, easily finding a home with one of the indoor companies.

But he did not. He was dead by the time that Paul's and Blackfriars reopened, and he died at the hand of Haughton's principal collaborator, John Day. ${ }^{46}$ Indeed, it was Day who went on to become a writer for the children's companies. Porter was a playwright for the Admiral's Men and - as far as we know - only for the Admiral's Men.

Those who write about individual playwrights may sometimes overemphasize what is special about that individual. All academic commentators need to make clear what is distinctive about their chosen subject — and this need may prompt us to depict the specialness of what attracts us more strongly than it deserves. In truth, all stage writers had to respond to common pressures: debt, company requirements, the risk of imprisonment for politically risky material, the need to pursue dramatic fashion, and the need to cope with theatre closures. These pressures, I suppose, are some of the social considerations that lie behind the broad and theoretical movement away from the author as a point of reference in literary studies. Indeed, the growth of repertory studies is one manifestation of this shift, and at times it has been explicitly so - most eloquently, perhaps, in Lucy Munro's account. ${ }^{47}$ This essay does not aim to commandeer repertory studies for author-based 
criticism. But I do suggest that by thinking about the contributions of playwrights we may better understand playing companies and that by investigating companies we may learn more about stage writers. And, of course, the attempt to say true things about companies and repertories necessarily faces the same kinds of challenge that writing about authors may involve.

The echoing of Romeo and Juliet that took place upon the Rose's stage in 1598 was part of a wider recourse to Shakespeare's tragedy, and part of a wider self-consciousness about the dramatic heritage of turn-of-the-century plays. By reflecting on this feature of the Admiral's repertory we may see a certain confluence between what was happening at the Rose in 1598 and at Paul's and Blackfriars a year or two later. The writers who composed Antonio and Mellida, Poetaster, and Blurt, Master Constable were themselves Admiral's dramatists. And Haughton and Porter were their peers.

Charles Cathcart

\section{Notes}

1 William Haughton, Englishmen for My Money, Three Renaissance Usury Plays, ed. Lloyd Edward Kermode (Manchester, 2009), 165-274, and Henry Porter, Henry Porter's 'The Two Angry Women of Abingdon': A Critical Edition, ed. Marianne Brish Evett (New York, 1980). Citations of Englishmen and Two Angry Women are to these editions.

2 Roslyn Lander Knutson, The Repertory of Shakespeare's Company, 1594-1613 (Fayetteville, 1991), 5; see also Knutson, 'The Repertory', John D. Cox and David Scott Kastan (eds), A New History of Early English Drama (New York, 1997), 461-2.

3 Andrew Gurr, Playgoing in Shakespeare's London (Cambridge, 1987), 147-53, esp. 149. Gurr partly reaffirms and partly modifies this position in Gurr, Shakespeare's Opposites: The Admiral's Company, 1594-1625 (Cambridge, 2009), 52-4 and 168-9.

4 Keith Sturgess, Jacobean Private Theatre (London, 1987); Michael Shapiro, Children of the Revels: The Boy Companies of Shakespeare's Time and Their Plays (New York, 1977), 67-70.

5 Henslowe's Diary, ed. R.A. Foakes (Cambridge, 2002), 87, 89.

6 Ibid, 102, 105.

7 See J.M. Nosworthy, 'Notes on Henry Porter', Modern Language Review 35 (1940), $217-21$.

8 See Evett, 'The Two Angry Women of Abingdon', 11-20. 
9 See Neil Carson, A Companion to Henslowe's Diary (Cambridge, 1988), 57.

10 William Shakespeare, Romeo and Juliet, Stanley Wells and Gary Taylor (eds), The Complete Works (Oxford, 1988). All citations of Shakespeare are to this edition.

11 Christopher Marlowe, Tamburlaine the Great, Part Two, ed. J.V. Cunningham (Manchester, 1981).

12 The LION (Literature Online) database confirms the rareness of this expression, suggesting that no further recorded dramatic usage exists of 'night's candles' 'burning' until well after the Elizabethan period. http://lion.chadwyck.co.uk (accessed 19 January 2010). See MacDonald P. Jackson, Defining Shakespeare: 'Pericles' as Test Case (Oxford, 2003) for a discussion of LION's possible uses.

13 Two Angry Women 8.64; Evett, 'The Two Angry Women of Abingdon', 197; Romeo 1.5.109.

14 LION indicates that this correspondence may be more significant than the rather perfunctory shared language might suggest. The only other dramatic instance from Renaissance times of offering a 'seal' to a 'bargain' through a 'kiss' comes from Shakespeare's early The Two Gentlemen of Verona as Julia says, 'And seal the bargain with a holy kiss' (2.2.7). (Accessed 19 January 2010).

15 Evett, 'The Two Angry Women of Abingdon', 229; Romeo 1.5.44-5.

16 Henry Porter, The Two Angry Women of Abingdon, ed. Michael Jardine and John Simons (Nottingham, 1987), 55n.

17 Evett, 'The Two Angry Women of Abingdon', 52.

18 See Tom Rutter, 'Marlovian Echoes in the Admiral's Men Repertory: Alcazar, Stukeley, Patient Grissil', Shakespeare Bulletin 27 (2009), 27-38.

19 See Marlowe, The Jew of Malta, ed. N.W. Bawcutt (Manchester, 1978), 2.1.41.

20 Anon. [John Marston], The Metamorphosis of Pigmalions Image. And Certaine Satyres (London, 1598); Anon. [John Marston], The Scourge of Villanie (London, 1598); Anon. [Everard Guilpin], Skialetheia. Or, A Shadowe of Truth, in Certaine Epigrams and Satyres (London, 1598).

21 William Shakespeare, The Tragedie of King Richard the Second (London, 1598).

22 George Chapman, The Blinde Begger of Alexandria, most pleasantly discoursing his variable humours, in disguised shapes full of conceite and pleasure (London, 1598).

23 See Lynda E. Boose, 'The 1599 Bishops' Ban, Elizabethan Pornography, and the Sexualisation of the Jacobean Stage', Richard Burt and John Michael Archer (eds), Enclosure Acts: Sexuality, Property, and Culture in Early Modern England (Ithaca, NY, 1994), 185-200.

24 Reavley Gair, The Children of St Paul's: The Story of a Theatre Company, 1553-1608 (Cambridge, 1982).

25 The Scourge of Villanie, H4v. 
26 The First Part of the Return to Parnassus, The Three Parnassus Plays, ed. J.B. Leishman (London, 1949).

27 See Roger Stilling, Love and Death in Renaissance Tragedy (Baton Rouge, 1976), 83-9.

28 Philip J. Finkelpearl, John Marston of the Middle Temple: An Elizabethan Dramatist in His Social Setting (Cambridge, MA, 1969), 132-3.

29 Thomas Dekker, A Critical Old-Spelling Edition of Thomas Dekker's 'Blurt, Master Constable’ (1601), ed. Thomas Leland Berger (Salzburg, 1979), 1.1.91-2, 3.1.129, 4.1.20; John Marston, The Plays of John Marston, ed. H.H. Wood, 3 vols (Edinburgh, 1933-9), 3.184.

30 John Marston and others, The Insatiate Countess, ed. Giorgio Melchiori (Manchester, 1984), 3.1.1-85; see Michael Scott, 'Marston's Early Contribution to The Insatiate Countess', Notes and Queries 221 (1977), 116-17, and Thomas Middleton, The Family of Love, ed. Simon Shepherd (Nottingham, 1979), 11. 121-88.

31 Charles Cathcart, Marston, Rivalry, Rapprochement, and Jonson (Aldershot, 2008), 115-16.

32 Henslowe's Diary, 124, 203 and elsewhere, 122 and elsewhere.

33 Henslowe's Diary, 85 and elsewhere, 201 and elsewhere.

34 Cyrus Hoy, Introductions, Notes and Commentaries to Texts in 'The Dramatic Works of Thomas Dekker', 4 vols (Cambridge, 1981), 4.61.

35 Anon. [Thomas Dekker, William Haughton, and Henry Chettle], A Pleasant Comoedie of Patient Grissill (London, 1603).

36 I.T. [John Tatham], Grim the Collier of Croydon, or The Devil and His Dame; With the Devil and St. Dunstan in Anon., A Choice Ternary of English Plays (London, 1662).

37 Marlowe, Lusts Dominion; or, The Lascivious Queen (London, 1657). This duodecimo had a first issue in which no author is named. See The Dramatic Works of Thomas Dekker, ed. Fredson Bowers, 4 vols (Cambridge, 1953-61), 4.117.

38 Henslowe's Diary, 65 etc.

39 Ibid, 134.

40 Ibid, 131. On Lust's Dominion and The Spanish Moor's Tragedy, see Hoy, Introductions, Notes and Commentaries, 4.56-8.

41 Lust's Dominion, 5.1.72-3, in The Dramatic Works of Thomas Dekker, vol. 4; Romeo, 2.1.127-28.

42 See K. Gustav. Cross, 'The Authorship of Lust's Dominion', Studies in Philology 55 (1958), 39-61, and Charles Cathcart, 'Lust's Dominion; or, The Lascivious Queen: Authorship, Date, and Revision', Review of English Studies 52 (2001), 360-75. 
43 See A.J. Hoenselaars, Images of Englishmen and Foreigners in the Drama of Shakespeare and His Contemporaries: A Study in Stage Characters and National Identity in English Renaissance Drama (London and Toronto, 1992).

44 G.K. Hunter, 'Porter, Henry (d. 1599)', The Oxford Dictionary of National Biography (Oxford, 2004) http://www.oxforddnb.com/view/article/22568 (accessed 21 Dec 2006).

45 Henslowe's Diary, 63, 242-3.

46 See Hunter, 'Porter, Henry'.

47 Lucy Munro, 'Early Modern Drama and the Repertory Approach', Research Opportunities in Renaissance Drama 42 (2003), 1-33.

\section{Will Kemp, Shakespeare, and the Composition of Romeo and Juliet}

'Enter Will Kemp', states Romeo and Juliet's 1599 second quarto in its uniquely specific stage direction towards the end of scene $17 .{ }^{1}$ This uniqueness makes the quarto, which editors know as Q2, a crucially important witness to the play's early performances, and to Kemp's career with Shakespeare and the Lord Chamberlain's Men. The Romeo and Juliet quartos, however, contain a number of other curious references to Kemp which act as further evidence of the working relationship between the dramatist and his company's star clown. A comparison of the play's two earliest quartos, Q1 of 1597 and Q2 of 1599 , shows the clown role to be both malleable and formative in the work's ongoing generic development. A study of Kemp in the play, through the textual anomalies which separate the printed quartos, thus provides a record of some of the transformations Romeo and Juliet underwent during the first years of its existence, as the company corrected, revised, abridged, and changed the scripts in order to capitalize on and contain the famous clown's distinctive talents.

Shakespeare wrote Romeo and Juliet in approximately 1595. Until quite recently, critics have considered the play's first printed edition, Q1, a 'bad' theatrical quarto, an approach which has tended to limit scholarly engagement with the text. ${ }^{2}$ Q2 appeared in 1599, printing a much longer version of the play. Scholars consider Q2 to be the 'good' quarto, deriving in the main from Shakespeare's 'foul papers'; despite the 1597 quarto's status as the earliest printed edition of the play, it is actually a theatrical adaptation of the longer text and thus a later version of the play as staged. ${ }^{3} \mathrm{Q} 1$ has, however, 